\title{
EVALUASI KINERJA PEGAWAI DALAM MENINGKATKAN KEMANDIRIAN ANAK CACAT TUNA NETRA PADA UNIT PELAKSANA TEKNIS DINAS PANTI REHABILITAS PENYANDANG CACAT NETRA PROVINSI SUMATERA SELATAN
}

\author{
Antartila Rizki Aziz \\ Sekolah Tinggi Ilmu Administrasi (STIA) Satya Negara Palembang \\ Email: antartilarezkiaaziz@gmail.com
}

\begin{abstract}
ABSTRAK
Penelitian ini bertujuan Untuk mengetahui Untuk mengetahui kinerja Unit Pelaksana teknis di Unit Pelaksana Teknis Dinas Panti Rehabilitasi Penyandang Cacat tuna Netra Provinsi Sumatera Selatan. dan disamping itu juga untuk faktor-faktor apa saja yang menghambat Unit Pelaksana teknis di Unit Pelaksana Teknis Dinas Panti Rehabilitasi Penyandang Cacat tuna Netra Provinsi Sumatera Selatan Penelitian ini menggunakan metode jenis penelitian yang dilakukan adalah penelitian kualitatif. penelitian kualitatif adalah adalah prosedur penelitian yang menghasilkan data deskriptif yang berupa kata-kata tertulis atau lisan dari orang-orang dan perilaku yang dapat diamati. Pengumpulan data di lakukan dengan teknik wawancara, observasi, dekumentasi.

Hasil penelitian di lapangan diperoleh Hasil wawancara Unit Pelaksana Teknis Dinas Panti Rehabilitas Penyandang cacat Tuna Netra Provinsi Sumatera Selatan hasil kerja yang pada umumnya sudah dilaksanakan dengan baik, dimana dari hasil kerja yang selama ini dilaksanakan sudah dilakukan dengan baik sesuai dengan juklak (Petujuk pelaksanaan) dan juknis (petujuk tehnis) tetapi ada satu kendala yaitu sarana dan prasarana yang masih kurang dan sudah tidak memadai dipergunakan lagi. Selebih dari itu semua telah terlasana dengan baik.

Evaluasi kinerja pegawai dengan indicator meliputi ; prestasi kerja, kemampuan, disiplin dan prilaku pegawai menunjukan bahwa evaluasi kerja yang selama ini dilakukan oleh Unit Pelaksana Teknis Dinas Panti Rehabilitas Penyandang cacat Tuna Netra Provinsi Sumatera Selatan sudah dilaksanakan dengan baik.
\end{abstract}

Kata Kunci : Evaluai kinerja pegawai Meningkatkan Kemandirian Anak Cacat Tuna Netra Pada Dinas Uptd Panti Rehabilitas Penyandang Cacat Netra Provinsi Sumatera Selatan

\section{A. PENDAHULUAN}

Evaluasi Kinerja Pembagian Tugas di Unit Pelaksana Teknis Dinas Panti Rehabilitasi Penyandang Cacat tuna Netra Provinsi Sumatera Selatan, adalah salah satu cara yang dilakukan untuk mencapai kinerja yang baik. Pelaksanaan tugas pada Unit Pelaksana Teknis Dinas Panti Rehabilitasi Penyandang Cacat tuna Netra Provinsi Sumatera Selatan selalu mengadakan rapat internal bersama sebelum semua para aparatur yang bekerja untuk meninjau kemabali hasil kerja selama seminggu, sehingga selanjutnya aparatur bisa efektif dalam bekerja sama.

\begin{abstract}
Proses pembangunan nasional seluruh warga negara Indonesia
\end{abstract} mempunyai hak dan kewajiban yang sama untuk ikut berpartisipasi dalam berbagai bidang sesuai dengan kemampuan yang di miliki penyandang cacat adalah salah satu kelompok warga yang merupakan pengguna dan salah satu populasi dalam kelompok yang berkepentingan yang ikut menentukan keberhasilan pembangunan.

Menurut pasal 15 Undang-Umdang No. 20 tahun 2003 tentang Sisdiknas, bahwa jenis pendidikan bagi Anak berkebutuan khusus adalah Pendidikan Khusus. Pasal 32 (1) Undang-Undang No. 
20 tahun 2003 memberikan batasan bahwa Pendidikan khusus merupakan pendidikan bagi peserta didik yang memiliki tingkat kesulitan dalam mengikuti proses pembelajaran karena kelainan fisik, emosional, mental, sosial, dan/atau memiliki potensi kecerdasan dan bakat istimewa. Menurut pasal 130 (1) Peraturan Pemerintah No. 17 Tahun 2010 Pendidikan khusus bagi peserta didik berkelainan dapat diselenggarakan pada semua jalur dan jenis pendidikan pada jenjang pendidikan dasar dan menengah

Sebagai warga negara Indonesia kedudukan, hak, kewajiban peran penyandang cacat tuna netra adalah sama dengan warga negara lainnya dan sesuai dengan amanah Undang-Undang Dasar 1945 pasal 27 Ayat (2) oleh karena itu, peningkatan dan penggalian potensi para penyandang cacat, termasuk penyandang cacat, netra merupakan upaya penting yang wajib dilakukan sehingga dapat didayagunakan untuk mendapatkan pekerjaan dan penghidupan yang layak bagi kemanusiaan.

Evaluasi kinerja merupakan tahapan penilaian individu tahunan berdasarkan tolak ukur tertentu yang dinilai. Pengembangan aparatur merupakan tahapan dari hasil evaluasi kinerjanya, sehingga akan diketahui sejauh mana perbaikan yang perlu dilakukan kepada aparatur atau pegawai tersebut atas target kinerja yang dicapai. Evaluasi kinerja, sebagai tahapan dari manajemen kinerja. Penilaian atau evaluasi kinerja dapat diketahui sejauh mana pencapaian target kinerja aparatur sesuai dengan tugas dan fungsinya. Tujuan evaluasi kinerja adalah untuk menjamin pencapaian sasaran dan tujuan dari instansi tersebut. Evaluasi kinerja dilakakukan untuk mengetahui sejauhmana pelaksanaan tugas di Unit
Pelaksana Teknis Panti Rehabilitasi Penyandang Cacat tuna Netra Provinsi Sumatera Selatan terutama bila terjadi kelambatan/kelemahan penyimpangan.

Pengelolaan kinerja aparatur atau sumber daya manusia dilakukan agar sejalan dengan arah visi dan misi Unit Pelaksana Teknis Dinas Panti Rehabilitasi Penyandang Cacat tuna Netra Provinsi Sumatera Selatan. Evaluasi kinerja dapat di tempuh melalui perancangan atau desain dan perilaku aparatur atau Sumberdaya Manusia yang sesuai dengan kompetensi inti instansi terkait. Evaluasi kinerja yang dilakakukan oleh Unit Pelaksana Teknis Dinas Panti Rehabilitasi Penyandang Cacat Netra Provinsi Sumatera Selatan untuk membicarakan para pegawai yang dinilai oleh pimpinan tentang sejauh mana pencapaian kinerja yang telah dilakukan atau di capai oleh pegawai tersebut.

Penyelenggaraan pemerintahan yang baik diperlukan dukungan kemampuan dalam mengelola dan memberdayakan, potensi dan sumber daya yang tersedia. Pengembangan sumber daya manusia merupakan modal utama dalam pencapaian good governance. Perkembangan sumber daya manusia merupakan alat penentu keberhasilan pemerintah, sumber daya manusia menentukan tercapainya tujuan dari pemerintahan. Kemampuan sumber daya manusia yang handal, maka pemerintah dapat meningkatkan pelayanan kepada masyarakat. Penerapan e-government dilingkungan pemerintahan dapat terlaksana dengan baik apabila memperhatikan sumber daya manusianya yaitu kinerja. Pemerintahan pada hakikatnya bertujuan pada pelayanan publik (public service) yaitu memberikan berbagai pelayanan yang diperlukan oleh masyarakat. Penggunaan teknologi 
informasi dan komunikasi memberikan kemudahan dalam meningkatkan hubungan antara pemerintah, masyarakat dan pihak-pihak lain. Pelayanan yang diberikan oleh pemerintah bermacammacam mulai dari pelayanan tentang kesehatan, pendidikan, sosial, dan lain sebagainya. Salah satu pelayanan yaitu penyampaian informasi ketenagakerjaan melalui media informasi yaitu website yang dilakukan oleh Unit Pelaksana Teknis Dinas Panti Rehabilitasi Penyandang Cacat tuna Netra Provinsi Sumatera Selatan

Berdasarkan

pengamatan

sementara pada Unit Pelaksana Teknis Dinas Panti Rehabilitasi Penyandang Cacat tuna Netra Provinsi Sumatera Selatan, terdapat kendala dalam mengadakan evaluasi kinerja yaitu kelambatan dan penyimpangan yang terjadi akibat dari kurangnya sumber daya manusia. Sumber daya manusia yang sangat minim mengakibatkan kinerja pegawainya menjadi lemah, sehingga pelayanan terhadap masyarakat Provinsi Sumatera Selatan menjadi kurang efisien dan lambat. Sumber daya manusia merupakan salah satu faktor yang sangat menentukan bagi keberhasilan atau kegagalan suatu organisasi atau instansi pemerintahan dalam mencapai tujuan. Unit Pelaksana Teknis Dinas Panti Rehabilitasi Penyandang Cacat tuna Netra Provinsi Sumatera Selatan membutuhkan individu atau sumber daya manusia yang kompeten, handal dan visioner. Kompetensi sumber daya manusia yang dimiliki harus sejalan dengan arah visi dan misi Unit Pelaksana Teknis Dinas Panti Rehabilitasi Penyandang Cacat tuna Netra Provinsi Sumatera Selatan

Menurut pengamatan penulis pada Unit Pelaksana Teknis Dinas panti
Rehabilitasi Penyadang Cacat tuna Netra masih belum maksimalnya sumber daya manusia pada Unit Pelaksana Teknis Dinas Panti Rehabilitasi Penyandang Cacat tuna Netra Provinsi Sumatera Selatan. Bisa dilihat masih banyak kurangnya pegawai yang bekerja sebagai pendamping anak, Kurangnya potensi, pengalaman serta keahlian pegawai dalam pelatihan dan pengembangan. Kurangnya motivasi pegawai dalam melaksanakan tugas dan tanggung jawab dalam memberikan pelayanan.

Sumber daya manusia merupakan suatu daya yang bersumber dari manusia yang berkualitas serta profesional. Kemampuan aparatur Unit Pelaksana Teknis Dinas Panti Rehabilitasi Penyandang Cacat tuna Netra Provinsi Sumatera Selatan sebagai sumber daya manusia dalam suatu organisasi sangat penting arti dan keberadaannya bagi peningkatan produktifitas kerja di lingkungan organisasinya.

Selanjutnya potensi dan pengalaman juga merupakan faktor dalam mencapai kinerja yang baik, serta motivasi yang tinggi dari pegawai dalam melakukan pekerjaan. Secanggihcanggihnya sarana dan prasarana yang dimiliki Unit Pelaksana Teknis Dinas Panti Rehabilitasi Penyandang Cacat tuna Netra Provinsi Sumatera Selatan, tanpa ditunjang oleh sumber daya manusia yang berkualitas, dapat diperkirakan dinas tersebut sulit untuk maju dan berkembang sehingga dapat menghasilkan kinerja yang buruk.

\section{B. TEORI}

\subsection{Pengertian Evaluasi}

Istilah Evaluasi dapat disamakan dengan penaksiran (appraisal), pemberian angka (rating) dan penilaian (assesment). 
Evaluasi kinerja sangat penting untuk menilai akuntabilitas organisasi dalam menghasilkan pelayanan publik. Akuntabilitas bukan sekedar kemampuan menunjukkan bagaimana uang publik dibelanjakan, akan tetapi meliputi apakah uang tersebut dibelanjakan secara ekonomis, efektif, dan efisien.

Pendapat William N. Dunn, (2003:608) istilah evaluasi mempunyai arti yaitu:

"Secara umum istilah evaluasi dapat disamakan dengan penaksiran (appraisal), pemberian angka (rating) dan penilaian (assessment), kata-kata yang menyatakan usaha untuk menganalisis hasil kebijakan dalam arti satuan nilainya. Dalam arti yang lebih spesifik, evaluasi berkenaan dengan produksi informasi mengenai nilai atau manfaat hasil kebijakan.

Pengertian di atas menjelaskan bahwa evaluasi merupakan hasil kebijakan dimana pada kenyataannya mempunyai nilai dari hasil tujuan atau sasaran kebijakan. Bagian akhir dari suatu proses kerja adalah evaluasi kinerja. Evaluasi kinerja membantu pimpinan untuk mengambil keputusan dalam suatu kebijakan, nilai yang dihasilkan dari evaluasi membuat suatu kebijan bermanfaat bagi pelayanan publik.

Menurut Taliziduhu Ndraha evaluasi merupakan proses perbandingan antara standar dengan fakta dan analisa hasilnya (Ndraha, 2003:201). Kesimpulannya adalah perbandingan antara tujuan yang hendak dicapai dalam penyelesaian masalah dengan kejadian yang sebenarnya, sehingga dapat disimpulkan dengan analisa akhir apakah suatu kebijakan harus direvisi atau dilanjutkan.
Menurut Commonwealth of Australia Department of Finance (2004:3) Evaluasi biasanya didefinisikan sebagai kegiatan untuk mengukur keberhasilan pelaksanaan kebijakan. Secara umum, evaluasi dapat didefinisikan sebagai the systematic assessment of the extent to which:

\section{Program inputs are used to maximise} outputs (efficiency);

2. Program outcomes achieve stated objectives (effectiveness);

3. Program objectives match policies and community needs (appropriateness).

Menurut pendapat di atas, evaluasi adalah penilaian secara sistimatis untuk melihat sejauh mana efisiensi suatu program masukan (input) untuk memaksimalkan keluaran (output), evaluasi juga digunakan untuk mencapai tujuan dari program pencapaian hasil atau afaktifitas, dan kesesuaian program kebijakan dan kebutuhan masyarakat. Evaluasi juga termasuk salah satu kegiatan yang dilakukan untuk mengukur keberhasilan suatu kebijakan.

Sudarwan Danim mengemukakan definisi penilaian (evaluating) (Danim, 2000:14) adalah:

"Proses pengukuran dan perbandingan dan hasil-hasil pekerjaan yang nyatanya dicapai dengan hasil-hasil yang seharusnya. Ada beberapa hal yang penting diperhatikan dalam definisi tersebut, yaitu:

1. Bahwa penilaian merupakan fungsi organik karena pelaksanaan fungsi tersebut turut menentukan mati hidupnya suatu organisasi.

2. Bahwa penilaiaan itu adalah suatu proses yang berarti bahwa penilaian adalah kegiatan yang terus menerus 
dilakukan oleh administrasi dan
manajemen

3. Bahwa penilaian menunjukkan jurang pemisah antara hasil pelaksanaan yang sesungguhnya dengan hasil yang seharusnya dicapai"

Pendapat di atas dapat diperoleh gambaran bahwa evaluasi adalah suatu kegiatan yang dilakukan untuk mengukur serta membandingkan hasil-hasil pelaksanaan kegiatan yang telah dicapai dengan hasil yang seharusnya menurut rencana, sehingga diperoleh informasi mengenai nilai atau manfaat hasil kebijakan, serta dapat dilakukan perbaikan bila terjadi penyimpangan di dalamnya.

Evaluasi mempunyai karakteristik yang membedakannya dari metodemetode analisis kebijakan lainnya (Dunn, 2003:608-609) yaitu:

1. Fokus nilai. Evaluasi berbeda dengan pemantauan, dipusatkan pada penilaian menyangkut keperluan atau nilai dari sesuatu kebijakan dan program.

2. Interdependensi Fakta-Nilai. Tuntutan evaluasi tergantung baik "fakta" maupun "nilai".

3. Orientasi Masa Kini dan Masa Lampau. Tuntutan evaluatif, berbeda dengan tuntutan-tuntutan advokat, diarahkan pada hasil sekarang dan masa lalu, ketimbang hasil di masa depan.

4. Dualitas nilai. Nilai-nilai yang mendasari tuntutan evaluasi mempunyai kualitas ganda, karena mereka dipandang sebagai tujuan dan sekaligus cara.

Berdasarkan penjelasan di atas, karakteristik evaluasi terdiri dari empat karakter. Yang pertama yaitu fokus nilai, karena evaluasi adalah penilaian dari suatu kebijakan dalam ketepatan pencapaian tujuan dan sasaran kebijakan. Kedua yaitu interdependensi fakta-nilai, karena untuk menentukan nilai dan suatu kebijakan bukan hanya dilihat dari tingkat kinerja tetapi juga dilihat dan bukti atau fakta bahwa kebijakan dapat memecahkan masalah tertentu. Ketiga yaitu orientasi masa kini dan masa lampau, karena tuntutan evaluatif diarahkan pada hasil sekarang dan masa lampau sehingga hasil evaluasi dapat dibandingkan nilai dari kebijakan tersebut. Keempat yaitu dualitas nilai, karena nilai-nilai dari evaluasi mempunyai arti ganda baik rekomendasi berkaitan dengan nilai yang ada maupun nilai yang diperlukan dalam mempengaruhi pencapaian tujuan-tujuan lain.

Tabel 2.1

Kriteria Evaluasi

\begin{tabular}{|c|c|}
\hline Tipe Kriteria & Pertanyaan \\
\hline Efektivitas & Apakah hasil yang diinginkan telah dicapai? \\
\hline Efisiensi & $\begin{array}{l}\text { Seberapa banyak usaha diperlukan untuk } \\
\text { mencapai hasil yang diinginkan? }\end{array}$ \\
\hline Kecukupan & $\begin{array}{l}\text { Seberapa jauh pencapaian hasil yang } \\
\text { diinginkan memecahkan masalah? }\end{array}$ \\
\hline Perataan & $\begin{array}{l}\text { Apakah biaya dan manfaat didistribusikan } \\
\text { dengan merata kepada kelompok-kelompok } \\
\text { tertentu? }\end{array}$ \\
\hline Resposivitas & $\begin{array}{l}\text { Apakah hasil kebijakan memuaskan } \\
\text { kebutuhan, preferensi atau nilai kelompok } \\
\text { kelompok tertentu? }\end{array}$ \\
\hline
\end{tabular}




\begin{tabular}{|l|l|}
\hline Ketepatan & $\begin{array}{l}\text { Apakah hasil (tujuan) yang diinginkan benar- } \\
\text { benar berguna atau bernilai? }\end{array}$ \\
\hline
\end{tabular}

(Sumber: Dunn, 2003:610)

Berdasarkan kriteria di atas, evaluasi membagi beberapa tipe kriteria diantaranya: efektivitas merupakan suatu altenatif mencapai hasil (akibat) yang diharapkan, atau mencapai tujuan dari diadakannya tindakan. Intinya adalah efek dari suatu aktivitas. Kedua yaitu efisiensi, berkenaan dengan jumlah usaha yang diperlukan untuk menghasilkan tingkat efektivitas tertentu. Ketiga, kecukupan merupakan sejauhmana tingkat efektivitas dalam memecahkan masalah untuk memuaskan kebutuhan, nilai atau kesempatan yang menumbuhkan masalah.

\subsubsection{Fungsi Evaluasi}

Evaluasi mempunyai beberapa fungsi (Tim Penyusun Modul Sistem AKIP;2007) yaitu:

a. Memberi informasi yang valid mengenai kinerja kebijakan, program dan kegiatan, yaitu mengenai seberapa jauh kebutuhan, nilai dan kesempatan telah dicapai, dengan evaluasi dapat diungkapkan mengenai pencapaian suatu tujuan, sasaran dan target tertentu.

b. Memberi sumbangan pada klarifiaksi dan kritik. Evaluasi memberi sumbangan pada klarifikasi dan kritik terhadap nilai-nilai yang mendasari tujuan dan target. Nilai diperjelas dengan mendefinisikan dan mengoperasikan tujuan dan target.

c. Memberi sumbangan pada aplikasi metode analisis kebijakan, termasuk perumusan masalah dan rekomendasinya. Informasi mengenai tidak memadainya suatu kinerja kebijakan, program dan kegiatan memberikan kontribusi bagi perumusan ulang kebijakan, program dan kegiatan. Evaluasi dapat pula menyumbangkan rekomendasi bagi pendefinisian alternatif kebijakan, yang bermanfaat untuk mengganti kebijakan yang berlaku dengan alternatif kebijakan yang lain. Menurut pendapat di atas, fungsi evaluasi untuk memberi informasi yang baik dan benar, kepada masyarakat. Memberi kritikan pada klarifikasi suatu nilainilai dari suatu tujuan dan target, kemudian Membuat suatu metode kebijakan untuk mencapai kinerja sehingga program dan kegiatan yang di evaluasi memberikan kontribusi bagi perumusan ulang kebijakan suatu kegiatan dalam organisasi atau instansi.

\subsubsection{Pengertian Kinerja}

Secara etimologi, kinerja berasal dari kata prestasi kerja (performance). Sebagaimana dikemukakan oleh Mangkunegara (2005:67) bahwa istilah kinerja berasal dari kata job performance atau actual performance (prestasi kerja atau prestasi sesungguhnya yang dicapai seseorang) yaitu hasil kerja secara kualitas dan kuantitas yang dicapai oleh seorang pegawai dalam melaksanakan tugasnya sesuai dengan tanggung jawab yang diberikan kepadanya.

Menurut Notoatmodjo (2003:123) bahwa kinerja tergantung pada kemampuan pembawaan (ability), kemampuan yang dapat dikembangkan (capacity), bantuan untuk terwujudnya performance (help), insentif materi maupun nonmateri (incentive), lingkungan (environment), dan evaluasi (evaluation). Kinerja dipengaruhi oleh kualitas fisik 
individu (ketrampilan dan kemampuan, pendidikan dan keserasian), lingkungan (termasuk insentif dan noninsentif) dan teknologi.

Menurut Malayu S.P Hasibuan ( 2012:117) kinerja (prestasi kerja) adlah suatuh hasil kerja yang dicapai seseorang dalam melaksankan tugas-tugas yang dibebankan kepadanya yang didasarkan atas kecakapan, pengalaman dan kesunguhan serta waktu.

Definisi kinerja menurut A.A. Anwar Prabu Mangkunegara (2006:67).

"Kinerja Karyawan (prestasi kerja) adalah hasil kerja secara kualitas dan kuantitas yang dicapai oleh seorang karyawan dalam melaksanakan tugasnya sesuai dengan tanggung jawab yang diberikan kepadanya"

Berdasarkan definisi di atas maka disimpulkan bahwa kinerja Sumber Daya Manusia adalah prestasi kerja atau hasil kerja baik kaulitas maupun kuantitas yang dicapai Sumber Daya Manusia persatuan periode waktu dalam melaksanakan tugas kerjanya sesuai dengan tanggung jawab yang diberikan kepadanya.

Menurut A. A. Prabu Mangkunegara (2006:20) manajemen kinerja merupakan proses perencanaa, pengorganisasian, pelaksanaan, dan pengendalian terhadap pencapaian kinerja dan dikomunikasikan secara terus menerus oleh pimpinan kepada karyawan, antara karyawan dengan atasannya langsung. Selanjutnya A. A. Prabu Mangkunegara mengemukakan tujuan dari pelaksanaan manajemen kinerja, bagi para pimpinan dan manajer adalah:

a. Mengurangi keterlibatan dalam semua hal;

b. Menghemat waktu, karena para pegawai dapat mengambil berbagai keputusan sendiri dengan memastikan bahwa mereka memiliki pengetahuan serta pemahaman yang diperlukan untuk mengambil keputusan yang benar

c. Adanya kesatuan pendapat dan menguarangi kesalahpahaman diantara pegawai tentang siapa yang mengerjakan dan siapa yang bertanggungjawab;

d. Mengurangi frekuensi situasi dimana atasan tidak memiliki informasi pada saat dibutuhkan;

e. Pegawai mampu memperbaiki kesalahannya dan mengidentifikasikan sebab-sebab terjadinya kesalahan atau inefesiensi.

Adapun tujuan pelaksanaan manajemen kinerja bagi para pegawai (Mangkunegara, 2006:20)adalah:

a. Membantu para pegawai untuk mengerti apa yang seharusnya mereka kerjakan dan mengapa hal tersebut harus dikerjakan serta memberikan kewenangan dalam mengambil keputusan;

b. Memberikan kesempatan bagi para pegawai untuk mengembangkan keahlian dan kemampuan baru;

c. Mengenali rintangan-rintangan peningkatan kinerja dan kebutuhan sumber daya yang memadai;

d. Pegawai memperoleh pemahaman yang lebih baik mengenai pekerjaan dan tanggungjawa kerja mereka.

Berdasarkan definisi dan tujuantujuan yang dikemukakan oleh Mangkunegara, maka manajemen kinerja adalah suatu proses perencanaan dan pengendalian kerja para aparatur dalam melaksanakan pekerjaannya, dalam tujuan Mangkunegara berbicara tentang bagaimana adanya pemahaman antara 
pimpinan dan bawahan dalam menyelesaikan, mengambil keputusan dan mendapatkan pemahaman yang baik tentang pekerjaan dan tanggung jawab.

\subsubsection{Prestasi Kerja}

Pemerintah telah mengeluarkan Peraturan Pemerintah Nomor 46 Tahun 2011 tentang Penilaian Prestasi Kerja Pegawai Negeri Sipil. Tujuannya untuk meningkatkan prestasi dan kinerja Pegawai Negeri Sipil. Peraturan Pemerintah ini merupakan penyempurna dari Peraturan Pemerintah Nomor 10 Tahun 1979 tentang Penilaian Pelaksanaan Pekerjaan Pegawai Negeri Sipil yang dianggap tidak sesuai lagi dengan perkembangan keadaan dan kebutuhan hukum. Penilaian prestasi kerja pegawai negeri sipil adalah suatuh proses penilaian secara sistematis yang dilakukan oleh pejabat penilai terhadap sasaran kerja pegawai dan perilaku kerja Pegawai Negeri Sipil. Dalam PerMen. KP Repoblik Indonesia Nomor: 5 Tahun 2017 yang dimaksud dengan: Kinerja adalah hasil dari pelaksanaan kontrak kinerja dan/atau tugas dan fungsi jabatan dalam organisasi.

\section{Dalam upaya meningkatkan}

kedisiplinan Pegawai Negeri Sipil tersebut sebenarnya pemerintah Indonesia telah memberikan suatu regulasi dengan dikeluarkannya Peraturan Pemerintah Nomor 53 Tahun 2010 tentang Peraturan Disiplin Pegawai Negeri Sipil. Pegawai Negeri Sipil sebagai aparat pemerintah dan abdi masyarakat diharapkan selalu siap sedia menjalankan tugas yang telah menjadi tanggung jawabnya dengan baik, namun realitanya sering terjadi dalam suatu instansi pemerintah, para pegawainya melakukan pelanggaran yang menimbulkan ketidakefektifan kinerja pegawai yang bersangkutan. Peraturan disiplin pegawai negeri sipil adalah peraturan yang mengatur kewajiban, larangan dan sanksi apabila kewajibankewajiban tidak ditaati atau dilanggar oleh Pegawai Negeri Sipil

Pengertian prestasi kerja (Ruky, 2002:12). disebut juga sebagai kinerja atau dalam bahasa Inggris disebut dengan performance. Pada prinsipnya, ada istilah lain yang lebih menggambarkan pada "prestasi" dalam bahasa Inggris yaitu kata "achievement". Tetapi karena kata tersebut berasal dan kata "to achieve" yang berarti "mencapai", maka dalam bahasa Indonesia diartikan menjadi "pencapaian" atau "apa yang dicapai".

Prestasi kerja adalah suatu hasil kerja yang dicapai seseorang dalam melaksanakan tugas-tugas yang dibebankan kepadanya yang didasarkan atas kecakapan pengalaman dan kesungguhan serta waktu (Hasibuan, 2003). Prestasi kerja merupakan gabungan dari tiga faktor penting yaitu kemampuan dan minat seorang pekerja, kemampuan dan penerimaan atas penjelasan delegasi tugas, serta peran dan tingkat motivasi seorang pekerja. Semakin tinggi ketiga faktor diatas, semakin besar pula prestasi kerja karyawan.

Rahmanto (2006) menyebutkan prestasi kerja atau kinerja sebagai tingkat pelaksanaan tugas yang bisa dicapai oleh seseorang, unit, atau divisi, dengan menggunakan kemampuan yang ada dan batasan-batasan yang telah ditetapkan untuk mencapai tujuan perusahaan. kata lain, pengukuran efisiensi menghendaki penentuan outcome, dan penentuan jumlah sumber daya yang dipakai untuk menghasilkan outcome tersabut. Di sector swasta dan dibanyak kasus sector publik, efisiensi, den produktivitas di angap sinonim. Selain efisensi produktivitas juga dikatakan dengan kualitas output, yang 
diukur berdasarkan beberapa kaida yang telah ditetapkan sabelumnya.

\section{Metode Penelitian}

Penelitian yang dilakukan adalah penelitian deskriptif kualitatif. Penelitian ini dilakukan dengan pendekatan kualitatif. Menurut Bogdan dan Moleong (2005 :3) penelitian kualitatif adalah adalah prosedur penelitian yang menghasilkan data deskriptif yang berupa kata-kata tertulis atau lisan dari orang-orang dan perilaku yang dapat diamati. Sekalipun demikian, data yang dikumpulkan dari penelitian kualitatif memungkinkan untuk dianalisis melalui suatu penghitungan. Artinya data yang dikumpulkan bukan berupa angkaangka, melainkan data tersebut berasal dari naskah wawancara, observasi dan dokumentasi. Sehingga yang menjadi tujuan dari penelitian kualitatif ini adalah ingin menggambarkan realita empirik di balik fenomena secara mendalam, rinci dan tuntas. (Afifudin \& Beni Ahmad Soebani, 2012)

\section{Teknik Pengumpulan Data}

Data yang diperlukan dalam penelitian ini dikumpulkan melalui wawancara untuk data primer, sedangkan observasi dan dokumentasi sebagai data sekunder. Adapun teknik pengumpulan data yang digunakan secara rinci sebagai berikut:

1. Wawancara

Wawancara adalah interaksi bahasa yang berlangsung antara dua orang dalam situasi saling berhadapan, yaitu yang melakukan wawancara meminta informasi kepada informan yang diteliti terkait pendapat dan keyakinnya. Jenis wawancara yang digunakan oleh peneliti berupa wawancara tidak terstruktur atau terbuka. Wawancara tidak terstruktur atau terbuka yaitu pelaksanaan wawancara tidak menggunakan pedoman wawancara yang telah tersusun secara sistematis dan lengkap, namun yang digunakan oleh peneliti hanya berupa garis-garis besar permasalahan yang akan ditanyakan.

Oleh karena itu, untuk dapat memperoleh informasi yang lebih dalam peneliti harus menentukan informan atau partisipan dan mengajukan pertanyaan dari pihakpihak yang dalam penelitian ini wawancara kepada Kepala panti, Pegawai dan Anak Cacat

2. Observasi

Observasi atau pengamatan dapat didefinisikan sebagai perhatian yang terfokus terhadap (kejadian, fenomena, gejala, atau situasi), dengan maksud dan tujuan untuk menafsirkan, mengungkapkan faktor-faktor penyebab, dan menemukan kaidahkaidah yang mengatur „kejadian, fenomena, gejala, atau sesuatu tersebut. (Sugiyono. 2009:83) Jenis observasi yang digunakan oleh peneliti adalah observasi langsung dengan aktivitas orang-orang yang sedang diamati.

\section{Dokumentasi}

Dokumentasi sebagai data untuk melengkapi hasil dari wawancara yang telah dilaksanakan/hasil wawancara dapat dipenuhi oleh data tersebut. Pengambilan data lewat dokumentasi sangat diharapkan karena berbagai informasi seluruh kegiatan akan di dokumentasikan. 


\section{PEMBAHASAN}

Pembahasan mengenai Evaluasi Kinerja Pegawai Dalam Meningkatkan Kemandirian Anak Cacat tuna Netra Pada Unit Pelaksana Teknis Dinas Panti Rehabilitas Penyandang cacat Tuna Netra Provinsi Sumatera Selatan. Pada bab ini penulis berusaha menganalisa data-data yang didapatkan dari hasil wawancara, dan hasil observasi. Terdiri dari hasil penelitian dan pembahasan hasil penelitiani. Peneliti berhasil memperoleh informasi dari beberapa informen dan penulis melakukan observasi dan wawancara di Unit Pelaksana Teknis Dinas Panti Rehabilitas Penyandang cacat Tuna Netra Provinsi Sumatera Selatan, dalam ovservasi tersebut penulis memperoleh data berupa dekomen dan hasil wawancara yang di mulai tanggal bulan April 2018. Adapun data yang diperoleh akan dijelaskan dengan evaluasi kinerja.

5.1.1 Evaluasi Kinerja Pegawai Dalam Meningkatkan Kemandirian Anak Cacat tuna Netra Pada Unit Pelaksana Teknis Dinas Panti Rehabilitas Penyandang cacat Tuna Netra Provinsi Sumatera Selatan

1. Analisis data tentang Prestasi kerja Pegawai

Pengertian prestasi kerja disebut juga sebagai kinerja atau dalam bahasa Inggris disebut dengan performance. Pada prinsipnya, ada istilah lain yang lebih menggambarkan pada "prestasi" dalam bahasa Inggris yaitu kata "achievement". Tetapi karena kata tersebut berasal dari kata "to achieve" yang berarti "mencapai", maka dalam bahasa Indonesia sering diartikan menjadi "pencapaian" atau "apa yang dicapai”. (Ruky:15)
Bernardin dan Russel (1993:378) memberikan definisi tentang prestasi kerja sebagai berikut : "performance is defined as the record of outcome produced on a ecified job function or activity during a specified time period" (Prestasi kerja didefinisikan sebagai catatan dari hasilhasil yang diperoleh melalui fungsifungsi pekerjaan tertentu atau kegiatan selama tempo waktu tertentu).

Definisi diatas dapat dipahami bahwa prestasi kerja lebih menekankan pada hasil atau yang diperoleh dari sebuah pekerjaan sebagai kontribusi pada perusahaan. Rahmanto menyebutkan prestasi kerja atau kinerja sebagai tingkat pelaksanaan tugas yang bisa dicapai oleh seseorang, unit, atau divisi, dengan menggunakan kemampuan yang ada dan batasanbatasan yang telah ditetapkan untuk mencapai tujuan perusahaan. (www. Feunpak. web. Id/ jima/isna.txt).

Pengertian diatas prestasi kerja yang telah dicapai oleh Unit Pelaksana Teknis Dinas Panti Rehabilitas Penyandang cacat Tuna Netra Provinsi Sumatera Selatan dapat dilihat dari hasil wawancara peneliti kepada Kepala panti Ibu Tsiil Fini mengatakan:

"Prestasi kerja yang telah dicapai oleh pegawai di Unit Pelaksana Teknis Dinas Panti Rehabilitas Penyandang cacat Tuna Netra Provinsi Sumatera Selatan adalah cukup baik dalam melatih anak-anak walau kadang menerima keluhan dan laporan dari pelatih anak cacat masih banyak mengalami kesulitan dalam melatih anak karena kondisi anak penuh keterbatasan, di latih terhadap kinerja yang dilakukan oleh Unit Pelaksana Teknis Dinas Panti Rehabilitas Penyandang cacat Tuna Netra Provinsi 
Sumatera Selatan dalam memberikan pelayanan terhadap anak peserta yang mengikuti pelatihan di Unit Pelaksana Teknis Dinas Panti Rehabilitas Penyandang cacat Tuna Netra Provinsi Sumatera Selatan di harapkan agar lebih bersaban dan di tingkatkan lagi." (wawanacara, tgl 20 April 2018) "Sedangkan menurut pegawai bahwa Unit Pelaksana Teknis Dinas Panti Rehabilitas Penyandang cacat Tuna Netra Provinsi Sumatera Selatan telah mengupayakan semaksimal mungkin perencaan dengan tepat terhadap program pelatihan kepada peserta serta pengembangan pelatihan serta pemasaran bagi peserta yang telah selesai mengikuti pelatihan untuk disalurkan penyandang cacat yang membutuhkan." (wawancara, tgl 20 April 2018)

Berdasarkan Hasil wawancara tersebut terlihat bahwa dalam prestasi kerja petugas khususnya Pegawai Negeri Sipil sudah memberikan pelatihan pelayanan publik dengan baik kepada anak dan telah melaksanakan tugas dan kewajibannya sebagai abdi negera dengan baik.

Hasil wanwancara Unit Pelaksana Teknis Dinas Panti Rehabilitas Penyandang cacat Tuna Netra Provinsi Sumatera Selatan hasil kerja yang diharapkan, pada umumnya sudah dilaksanakan dengan baik, dimana dari hasil kerja yang selama ini dilaksanakan sudah dilakukan dengan baik sesuai dengan juklak (Petujuk pelaksanaan) dan juknis (petujuk tehnis) tetapi ada satu kendala yaitu sarana dan prasarana yang masih kurang dan sudah tidak memadai dipergunakan lagi. Selebih dari itu semua telah terlasana dengan baik.

Informen tentang evaluasi dengan indicator meliputi ; prestasi kerja, kemampuan, disiplin dan prilaku pegawai menunjukan bahwa evaluasi kerja yang selama ini dilakukan oleh Unit Pelaksana Teknis Dinas Panti Rehabilitas Penyandang cacat Tuna Netra Provinsi Sumatera Selatan sudah dilaksanakan dengan baik. Disisi lain dimensi kinerja dengan indicator; 1). Tingkat disiplin pegawai, 2). Tingkat kemampuan Pegawai, dan 3). Prilaku Pegawai, dari tanggapan responden di atas menunjukan bahwa tingkat kinerja pegawai dilingkungan Unit Pelaksana Teknis Dinas Panti Rehabilitas Penyandang cacat Tuna Netra Provinsi Sumatera Selatan sudah menunjukan kriteria baik walau masih ada sedikit kekurangan tidak menjadi kendala yang serius dalam memberikan pelayanan kepada masyarakat.

Hambatan yang paling dirasakan adalah Masi kekurangan dana dan calon relawan/pengurus yang siap mengabdi. Pengurus secara periodik telah melakukan upaya kaderisasi bagi calon relawan/pengurus melalui sosialisasi setiap ada pertemuan yang dilakukan secara perorangan maupun kelompok.

$$
\text { Walaupun telah melaksanakan }
$$
upaya kaderisasi namun kenyataannya sangat sedikit yang mau aktif, hal ini disebabkan bahwa pada umumnya orangorang tidak mau susah, apalagi dibebani untuk mengurus anak-anak dengan kecacatan yang sudah pasrti tidak akan mendapat imbalan.

Kendala lain adalah luas tanah yang dimiliki sangat sempit sehingga sulit untuk melaksanakan pengembangan pembangunan yang lebih maksimal prasarana merupakan bagian yang sangat diperlukan. Untuk mengantisipasi berbagai kemungkinan yang dapat menghambat perkembangan UPTD panti Rehabilitasi Penyandang CacatTuna Netra maka segenap organ yayasan dengan penuh rasa 
hormat mengetuk seluruh hati masyarakat, pengusaha, para dermawan dan relawan untuk ikut srta memperhatikan kesejahteraan anak-anak berkebutuhan khusus yang menjadi binaan pembina.

\section{E. KESIMPULAN}

Dari hasil pembahasan pada Bab sebelumnya, dikesimpulan hasil pembahasan sekaligus alternatif pemecahan masalah yang dihadapi objek penelitian Evaluasi kinerja pegawai dengan indicator meliputi ; prestasi kerja, kemampuan, disiplin dan prilaku pegawai menunjukan bahwa evaluasi kerja yang selama ini dilakukan oleh Unit Pelaksana Teknis Dinas Panti Rehabilitas Penyandang cacat Tuna Netra Provinsi Sumatera Selatan sudah dilaksanakan dengan baik.. Kemampuan kerja yang dimiliki oleh petugas sudah memenuhi tuntutan dari aktivitas kerja, sehingga pelaksanaan kerja sudah dilakukan dengan cukup baik.

\section{DAFTAR PUSTAKA}

AA. Anwar Prabumangkunegara.2006. Manajemen SDM. Bandung:Rosdakarya

Azwar, Saifuddin, 2010. Metode Penelitian, Pustaka Pelajar,Yogyakarta.

Dunn,William N, 2003. Analisis Kebijakan Publik. Yogyakarta: Gajah Mada Universitas Press

Dwiyanto, Agus. 2017. "Budaya Paternalisme dalam Birokrasi Pelayanan Publik", Policy Brief, Center for Population and Policy Studies, UGM,Yogyakarta.

Dharma,Surya,2006. Pengenmbangan SDM Berbasis

Kompetensi.Yogyakarta:Amara Book
Howlett, M \& M, Ramesh, Studying Public Policy: Policy Cycles and Policy

Subsystems, Oxford University Press, New York, 1995.

Buchari Zainun.2015.Organisasi dan Manajemen; Jakarta ; Balai Aksara

Dolet Unaradjan, 2003 Manajemen Disiplin ; Jakarta ; PT. Gramedia Widiasarana Indonesia

Fahmi Irham, 2014, Prilaku Organisasi : Bandung Alfabeta

Malayu Hasibuan, SP.2002. Manajemen Sumber Daya Manusia. Bumi Aksara:Jakarta

Mangkunegara, Anwar Prabu. 2005. Evaluasi Kinerja Sumber Daya Manusia. Bandung: Rafiak Aditama.

Sadili,Samsudin.2006. Manajemen Sumber Daya Manusia. Bandung:Pustaka Setia

Moleong.Lexi. J.2005. Metode Penelitian Kualitatif. Remaja Rosdakarya: Bandung.

Robbins, Stephens P,2006 Perilaku Organisasi, Edisi Bahasa Indonesia, Jilid I dan II, PT.Prenhallindo, Jakarata,

Simanjuntak, Payaman J. 2005. Manajemen dan Evaluasi Kerja. Jakarta: Lembaga Penerbit FKEUI

Ruky,Achmad S. 2003. Sumber Daya Manusia Berkualitas Mengubah Visi Menjadi Realitas. Gramedia Pustaka Utama:Jakarta

T.Hani Handoko, 2002, Riset Sumber Daya Manusia, edisi refisi. Bandung:Sulita

Thoha,Mifftah, 2008. Ilmu Administrasi Publik Kontenporer. Jakarta: Prenada Media Group

Wirawan,2009. Budaya dan Iklim Organisasi. Jakarta:Salemba Empat 
Peraturan Pemerintah Nomor 30 Tahun 1980 Tentang Peraturan Disiplin Pegawai Negeri Sipil.

Yani M, 2012, Majajemen Sumberdaya Manusia, Jakarta, Mitra Wacana Media.

Zamzam, Fakhry, Havis Aravik, 2016. Manajemen SDM Berbasis Syariah, Bogor: CV. RWTC Success 